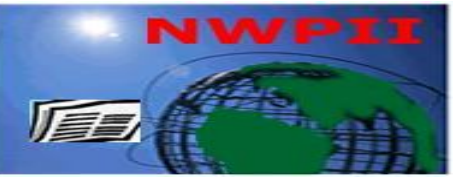

American Journal of Biomedical Sciences

ISSN: 1937-9080

nwpii.com/ajbms

\title{
High Sucrose Low Magnesium Diet Modulates the Expression of PI3K and ERK2 in Different Tissues of Weanling Rats
}

\author{
Meenakshi Garg, Ravi Kiran and Devi Dayal Bansal*
}

Department of Biochemistry, Panjab University, Chandigarh-160014, India.

*Corresponding author

Dr. Devi Dayal Bansal, Professor

Department of Biochemistry

Panjab University

Chandigarh -160014 , India.

Phone: 0172-2534131, 0172-2534134.

Fax: 91-0172-2541409

E-mail: bansal_devi@yahoo.com

Received: 22 June 2010; $\mid$ Revised: 18 July 2010; $\mid$ Accepted: 26 July 2010

\begin{abstract}
Activation of the insulin receptor initiates signaling through both the phosphatidylinositol (PI) 3-kinase and the mitogen-activated protein kinase [MAPK, also referred to as extracellular signal-regulated kinases (ERK1/2)] pathways. The present study was undertaken to evaluate the effects of feeding high sucrose low magnesium diet to weanling rats on the insulin signal transduction pathways. To accomplish this, a nongenetic type 2 diabetic rat model was developed in the laboratory by feeding high sucrose+ $\mathrm{Low} \mathrm{Mg}$ (HSLM) diet to weanling rats and the expression of the downstream effectors of insulin signaling pathway was studied. The Expression of ERK2 and PI3 Kinase was assessed in adipose tissue, skeletal muscle and liver of control and experimental diet fed rats. The results obtained clearly indicated a decrease in the expression of ERK2 and PI3 Kinase in all the three tissues from HSLM diet fed rats when compared to control rats, thereby confirming that Sucrose+ Low Mg feeding ultimately leads to insulin resistance via a decrease in the expression of the downstream effectors of the insulin signaling pathway.
\end{abstract}

Keywords: PI3K, ERK expression, Sucrose+ Low Mg, adipose tissue, skeletal muscle, liver.

\section{Introduction}

Diet composition has been proposed as one of the causes of the increasing prevalence of obesity, insulin resistance and the metabolic syndrome [1]. Increased access to diets enriched in fat or foods and beverages containing added simple sugars, e.g. sucrose or high fructose corn syrup lead to positive energy balance and therefore, fat or weight gain [1]. Dietary nutrients can also modulate insulin action. In rats, diets enriched in sucrose or fructose produce hepatic insulin resistance prior to adipose tissue and skeletal muscle, and independently of the changes in body composition [2]. Magnesium deficiency is

(C) 2011 by NWPII. All rights reserved. 
frequently associated with changes in carbohydrate homeostasis [3]. Attempts have been made to correlate hypomagnesaemia and reduced erythrocyte $\mathrm{Mg}$ concentration with poor glycemic control and the development of complications in diabetic patients [4]. Because a low $\mathrm{Mg}$ concentration may be a consequence or a cause of insulin resistance [4], it may be premature to assign a primary role to $\mathrm{Mg}$ in abnormal carbohydrate metabolism.

Insulin action in target tissues is mediated by the heterotetrameric insulin receptor. Insulin signaling is initiated by the activation of insulin receptor tyrosine kinase, leading to the phosphorylation of insulin receptor substrates 1 and 2, thereby creating binding sites for the regulatory subunits of phosphatidylinositol 3kinase (PI3-kinase) and Grb/Sos complex [5]. PI3kinase appears to be particularly important for mediating most of the metabolic effects of insulin and its downstream signaling events [6]. PI 3kinase is activated by the docking of its p85 subunit to phosphorylated IRS-1 and is linked to the activation of glucose transport, p70 S6 kinase activation, and nuclear DNA synthesis and gene expression. PI 3-kinase also activates protein kinase Akt (protein kinase B) and leads to glucose transporter 4 (GLUT4) vesicle translocation and glucose transport activation. On the other hand, Shc and the Grb2/Sos complex link insulin receptor signaling to activation of the mitogenactivated protein kinase [MAPK or extracellular signal-regulated kinase (ERK1/2)] cascade [7]. MAPK activity is increased when Grb2/ Sos complex is recruited to the plasma membrane by an increase in the rate of exchange of guanosine triphosphate (GTP) for guanosine diphosphate (GDP) on Ras, which, in turn, activates MAPK kinase kinase (MEKK) leading to activation of MAPK kinase (MEK1), a threonine- tyrosine kinase that phosphorylates and activates ERK1 and ERK2 [8]. ERK2 is the most abundant MAPK isoform in skeletal muscle. Several studies have shown that activation of the PI3-kinase signaling pathway in response to insulin is reduced in muscles of obese and Type 2 diabetic subjects and in animal models of insulin resistance $[9,10]$. One such animal model of insulin resistance is the non diabetogenic HSLM diet fed rat model. The rats in this model are characterized by hyperglycemia, hyperinsulinemia and hypertriglyceridemia [11], conditions similar to those observed in the early stage of human Type 2 diabetes. Thus this HSLM diet fed rat model is ideal for the present study. Therefore, the present study was planned to raise a HSLM diet fed rat model by feeding a synthetic diet to weanling rats on the same basis as the adult rats [11] and to determine whether HSLM feeding results in change in the expression of ERK2 and PI3 Kinase in adipose tissue, skeletal muscle and liver.

\section{Materials and Methods}

Chemicals: TRIzol® reagent for total RNA isolation was procured from Invitrogen Corp, California, USA. Primers for ERK2 and PI3K were obtained from Sigma Chemicals Co., St. Louis, Mo., USA. M-MuLV RT-PCR Kit was purchased from Bangalore GeNei ${ }^{\mathrm{TM}}$, India. Kit for estimation of plasma glucose was obtained from Reckon Diagnostics Ltd., India. All other chemicals used were of analytical grade.

Animals and Diet: 24 Weanling male Wistar rats (bred in our facility), 21 day old and weighing about $30 \mathrm{~g}$ at the beginning of the study were randomly divided into four groups containing 6 rats each and were housed in polypropylene cages in a temperature-controlled room on a 12-h-light 12-h-dark cycle. The rats in the four groups were fed either a Starch+Normal Mg (Control) or Sucrose+Normal Mg (HS) diet or Starch+Normal Mg (LM) or Sucrose+Low Mg (HSLM) diet for a total period of 16 weeks. The diets were made up according to Table 1, and were fed to the rats in the form of pellets. Diets were freshly made up on a weekly basis and stored at $4^{\circ} \mathrm{C}$. Rats in the Control and HS group had free access to tap water whereas rats in the LM and HSLM group had free access to double distilled water. All the institutional guidelines for the care of animals were followed strictly.

\subsection{Biochemical Analyses}

Estimation of plasma glucose: Blood was drawn from the supraorbital sinus of ether anaesthized rats once the animals had reached an appropriate age and weight. To attain this aim, rats (C) 2011 by NWPII. All rights reserved. 
were fed different diets for a period of 6 weeks and blood was drawn every 2 weeks hence. Plasma was separated and the levels of plasma glucose were measured by the method of Trinder [12] using glucose oxidase. Briefly, $10 \mu \mathrm{l}$ of plasma was added to $1 \mathrm{ml}$ of working reagent.
Equal volumes of glucose standard and distilled water were added respectively to tubes marked standard and blank, containing $1 \mathrm{ml}$ of the working reagent. The contents of the tubes were then mixed well and incubated for $15 \mathrm{~min}$ at $37^{\circ} \mathrm{C}$ in a water bath. Colour developed was read at $510 \mathrm{~nm}$.

Table 1: Experimental diet composition in $\mathrm{g} / \mathrm{kg}$ diet ${ }^{\text {\& }}$

\begin{tabular}{|l|l|l|l|l|}
\hline Ingredient & $\begin{array}{c}\text { Starch +Normal } \\
\text { Mg diet }\end{array}$ & $\begin{array}{c}\text { Starch+Low Mg } \\
\text { diet }\end{array}$ & $\begin{array}{c}\text { Sucrose+Normal Mg } \\
\text { diet }\end{array}$ & $\begin{array}{c}\text { Sucrose +Low Mg } \\
\text { diet }\end{array}$ \\
\hline Sucrose & - & - & 658 & 658 \\
\hline Starch & 658 & 658 & - & - \\
\hline Casein & 188 & 188 & 188 & 188 \\
\hline Methionine & 1.9 & 1.9 & 1.9 & 1.9 \\
\hline Gelatin & 14.1 & 14.1 & 14.1 & 14.1 \\
\hline Safflower oil & 45.4 & 45.4 & 45.4 & 45.4 \\
\hline Bran & 37.6 & 37.6 & 37.6 & 37.6 \\
\hline Mineral Mix*\$ & 49.7 & 49.7 & 49.7 & 49.7 \\
\hline Vitamin Mix\# & 9.4 & 9.4 & 9.4 & 9.4 \\
\hline
\end{tabular}

${ }^{\&}$ By calories, the diets were $69 \%$ carbohydrate, $21 \%$ protein, and $10 \%$ fat. \#Supplied per kilogram of vitamin mix: $3 \mathrm{~g}$ thiamine mononitrate, $3 \mathrm{~g}$ riboflavin, $3.5 \mathrm{~g}$ pyridoxine $\mathrm{HC} 1,15 \mathrm{~g}$ nicotinamide, $8 \mathrm{~g} \mathrm{~d}$ calcium pantothenate, $1 \mathrm{~g}$ folic acid, $0.1 \mathrm{~g}$ d-biotin, $5 \mathrm{mg}$ cyanocobalamin, $500000 \mathrm{IU}(12.5 \mathrm{mg})$ cholecalciferol, $25 \mathrm{mg}$ acetomenaphthone, $2000000 \mathrm{IU}$ (600 mg) vitamin A acetate, $25000 \mathrm{IU}(22 \mathrm{~g}) d /-a$-tocophenyl acetate and $10 \mathrm{~g}$ choline chloride. *Supplied in per kilogram of mineral mix: $30.5 \mathrm{~g} \mathrm{MgSO}_{4} \cdot 7 \mathrm{H}_{2} \mathrm{O}, 65.2 \mathrm{~g} \mathrm{NaC1}, 105.7 \mathrm{~g} \mathrm{KC1}, 200.2 \mathrm{~g} \mathrm{KH}_{2} \mathrm{PO}_{4}, 38.8 \mathrm{~g} \mathrm{MgCO}_{3}$. $3 \mathrm{H}_{2} \mathrm{O}, 40.0 \mathrm{~g} \mathrm{FeCH}_{3} \mathrm{O}_{2} .5 \mathrm{H}_{2} \mathrm{O}, 512.4 \mathrm{~g} \mathrm{CaCO}_{3}, 0.8 \mathrm{~g} \mathrm{KI}, 0.9 \mathrm{~g} \mathrm{NaF}, 1.4 \mathrm{~g} \mathrm{CuSO}_{4} .5 \mathrm{H}_{2} \mathrm{O}, 0.4 \mathrm{~g} \mathrm{MnSO}$ and $0.05 \mathrm{~g} \mathrm{CoNH}_{3}$.

$\$$ A similar composition of mineral mixture was used in all the experimental groups, except for the addition of $\mathrm{MgO}$ and $\mathrm{MgSO}_{4} \cdot 2 \mathrm{H}_{2} \mathrm{O}$ to provide (per kg) $507.0 \mathrm{mg}$ of $\mathrm{Mg}$ in the control and high sucrose diets and $40.0 \mathrm{mg}$ of $\mathrm{Mg}$ in the low magnesium and the high sucrose low magnesium diets.

Table 2: PCR primers and Programs for quantitation of RNA*.

\begin{tabular}{|c|c|c|c|}
\hline cDNA & Forward Primer & Reverse Primer & PCR Program \\
\hline$\beta$-actin & 5'CTGACCGAGCTGGCTAC 3' & 5' CCTGCTTGCTGATCCACA 3' & 94/30/55/30/72/45/22 \\
\hline ERK2 & 5'TGAAGACACAGCACCTCAGC 3' & 5' GTCACGGTGCAGAACGTTAG 3' & 94/30/60/30/72/60/40 \\
\hline PI3K & 5' TTAAACGCGAAGGCAACGA 3' & 5' CAGTCTCCTCCTGCTGTCGAT 3' & 94/15/60/60/72/60/40 \\
\hline
\end{tabular}

*Primers were designed using the known sequences for the respective genes. Programs are given as denaturation temperature $\left({ }^{\circ} \mathrm{C}\right) /$ denaturation time(s)/annealing temperature $\left({ }^{\circ} \mathrm{C}\right) /$ annealing time $(\mathrm{s}) /$ elongation temperature $\left({ }^{\circ} \mathrm{C}\right) /$ elongation time $(\mathrm{s}) /$ number of cycles. Additionally, all programs started with a period of $94^{\circ} \mathrm{C}$ for $10 \mathrm{~min}$ and finished with 5 extra min at $72^{\circ} \mathrm{C}$. For example, the program for $\beta$-actin was $94^{\circ} \mathrm{C}$ for $10 \mathrm{~min}$ followed by $22 \mathrm{cycles}$ of $94^{\circ} \mathrm{C}$ for $30 \mathrm{sec}, 55^{\circ} \mathrm{C}$ for $30 \mathrm{sec}, 72^{\circ} \mathrm{C}$ for $45 \mathrm{sec}$, and ending with $5 \mathrm{~min}$ at $72^{\circ} \mathrm{C}$. 
Estimation of magnesium: At the end of 6 weeks of diet feeding, magnesium levels were determined every 2 weeks [13]. Suitable volumes of plasma were mixed well with $2 \mathrm{ml}$ of the working reagent in small tubes and read immediately at $570 \mathrm{~nm}$ against a blank containing equal volumes of double deionized water and working reagent. A range of appropriate standards were run similarly.

\subsection{Tissue Preparation and RNA isolation}

At the end of the 4 months of diet feeding the overnight fasted rats were sacrificed by cervical dislocation and the liver, skeletal muscle from the thigh and the adipose tissue from the epidydimal fat pad was separated, washed in ice cold normal saline and then used for Total RNA isolation. Total RNA was extracted using a commercially available reagent TRIzol ${ }^{\circledR}$ (Invitrogen Corp, California, USA). Briefly, 50-100 mg of tissue was homogenized in $1 \mathrm{ml}$ of TRIzol® reagent and processed according to Kit manufacturer's instructions. After that the concentration of total RNA was measured by spectrophotometry (Beckman Instruments, Fullerton, CA). The samples were stored in $-80^{\circ} \mathrm{C}$ freezer for carrying out RT-PCR study.

\subsection{RT-PCR}

The following primer sets were used for RTPCR. Rat ERK2 forward primer: 5'tgaagacacagcacctcagc 3', reverse primer: 5' gtcacggtgcagaacgttag 3', rat PI3K forward primer: 5' ttaaacgcgaaggcaacga 3', reverse primer: 5' cagtctcctcetgctgtcgat 3 ' and beta actin forward primer: 5'ctgaccgagctggctac 3'and reverse primer: 5' cctgcttgctgatccaca 3'. We used M-MuLV RTPCR Kit (GeNei ${ }^{\mathrm{TM}}$, Bangalore, India) according to the manufacturer's instructions. Oligo $\mathrm{d}(\mathrm{T})$ primers were used with this kit to reverse transcribe the mRNA from total RNA. cDNA was produced with $1 \mu \mathrm{g}$ of RNA as template. The gene-specific primers (Table 2) were designed by using available gene sequences. The oligomers were purchased from Sigma Chemicals Co. (St. Louis, Mo., USA). PCRs were run on a MiniCycler (Eppendorf, Germany). The programs (Table 2) were optimized for each primer pair to get a linear proportion between the amount of

Am. J. Biomed. Sci. 2011, 3(1), 11-22; doi: 10.5099/aj110100011 template used and the amount of product after the PCR reaction. All programs started with a $10-\mathrm{min}$ period at $94^{\circ} \mathrm{C}$ and ended with a 5-min extra elongation period at $72^{\circ} \mathrm{C}$. The PCR products were run on $2 \%$ agarose gels (Sigma). Gels were stained with ethidium bromide, visualized by ultraviolet light and photographed using Gel Doc XR System (BioRad). The bands were identified and quantified using the Multi-Analysis software of Gel Doc XR system (Biorad, Hercules, CA). The mRNA level of each enzyme was expressed as a ratio of each enzyme/ $\beta$-actin RNA. All the reactions were performed thrice.

Table 3: Percentage downregulation of MAPK as calculated by the normalization of the test with that of the control gene.

\begin{tabular}{|l|l|}
\hline Enzyme & \% Downregulation \\
\hline Adipose MAPK (LM) & 12.9 \\
\hline Adipose MAPK (HS) & 10.12 \\
\hline Adipose MAPK (HSLM) & 16.3 \\
\hline Muscle MAPK (LM) & 9.8 \\
\hline Muscle MAPK (HS) & 6.14 \\
\hline Muscle MAPK (HSLM) & 12.8 \\
\hline Liver MAPK (LM) & 26.6 \\
\hline Liver MAPK (HS) & 21.2 \\
\hline Liver MAPK (HSLM) & 32.1 \\
\hline
\end{tabular}

Table 4: Percentage downregulation of PI3K as calculated by the normalization of the test with that of the control gene.

\begin{tabular}{|l|l|}
\hline Enzyme & \% Downregulation \\
\hline Adipose PI3K (LM) & 25.1 \\
\hline Adipose PI3K (HS) & 15.9 \\
\hline Adipose PI3K (HSLM) & 31.4 \\
\hline Muscle PI3K (LM) & 39.2 \\
\hline Muscle PI3K (HS) & 30.4 \\
\hline Muscle PI3K (HSLM) & 40.5 \\
\hline Liver PI3K (LM) & 28.4 \\
\hline Liver PI3K (HS) & 5.7 \\
\hline Liver PI3K (HSLM) & 38.4 \\
\hline
\end{tabular}

\subsection{Statistical analysis}

Statistical analysis was performed using GraphPad InStat (GraphPad Inc., San Diego, CA, USA) software package. Results were expressed as mean and SD of six observations in each group. Further, the statistical significance of the (C) 2011 by NWPII. All rights reserved. 
differences among the various dietary groups was determined by subjecting the data to two way ANOVA with diet as the main effect, followed by inspection of all differences between pairs of means by Post Hoc test. Differences were considered statistically significant at $p<0.05$.

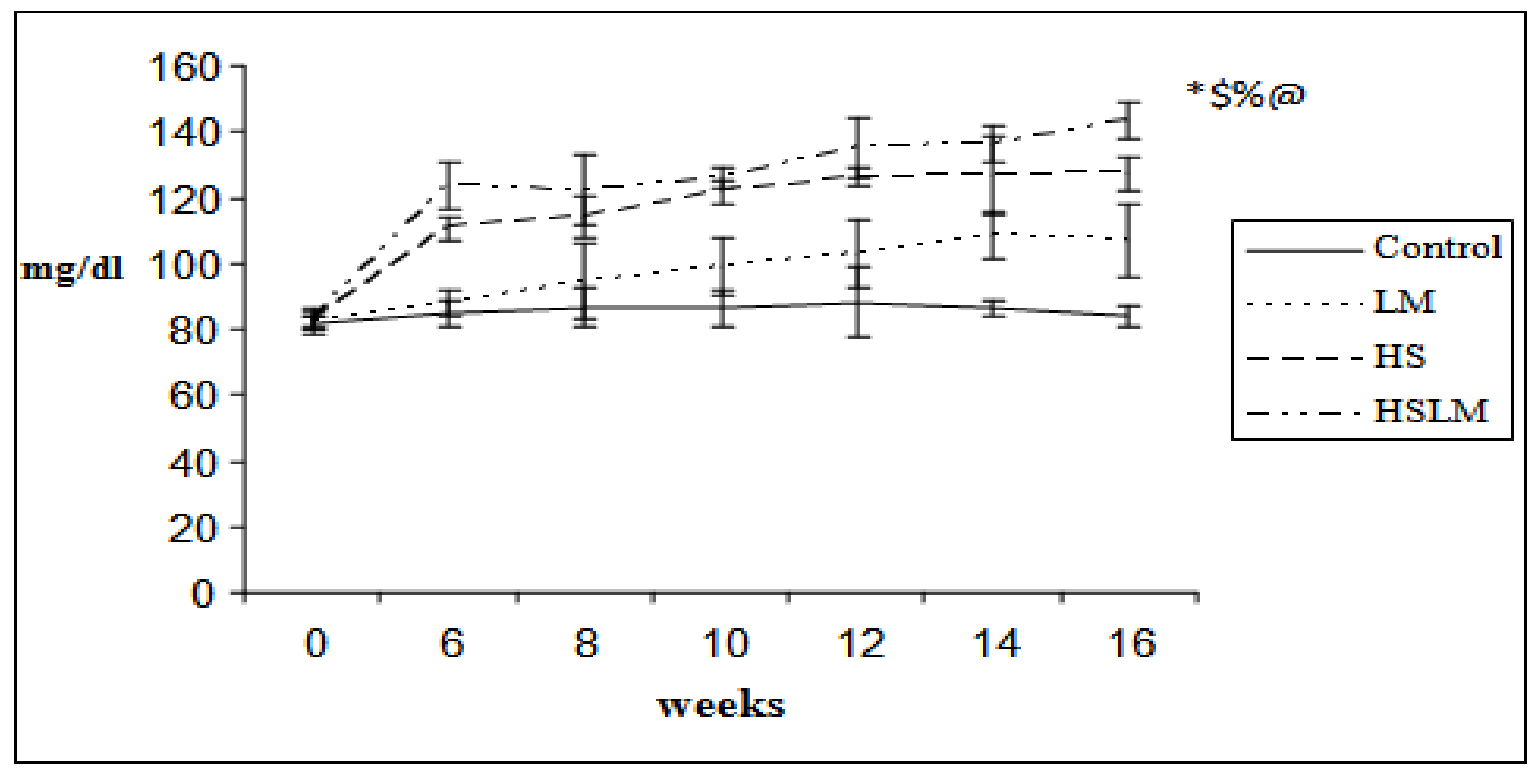

In all cases $\mathrm{p}<0.001$

* Significantly different from the initial value, ${ }^{\$}$ Significantly different from the control group, ${ }^{\%}$ Significantly different from the LM group, ${ }^{\circledR}$ Significantly different from the HS group.

Fig. 1: Levels of plasma glucose as measured at $6^{\text {th }}$ to $16^{\text {th }}$ week of diet feeding. The figure clearly shows that rats fed HSLM diet had increased plasma glucose levels as compared to the control rats.

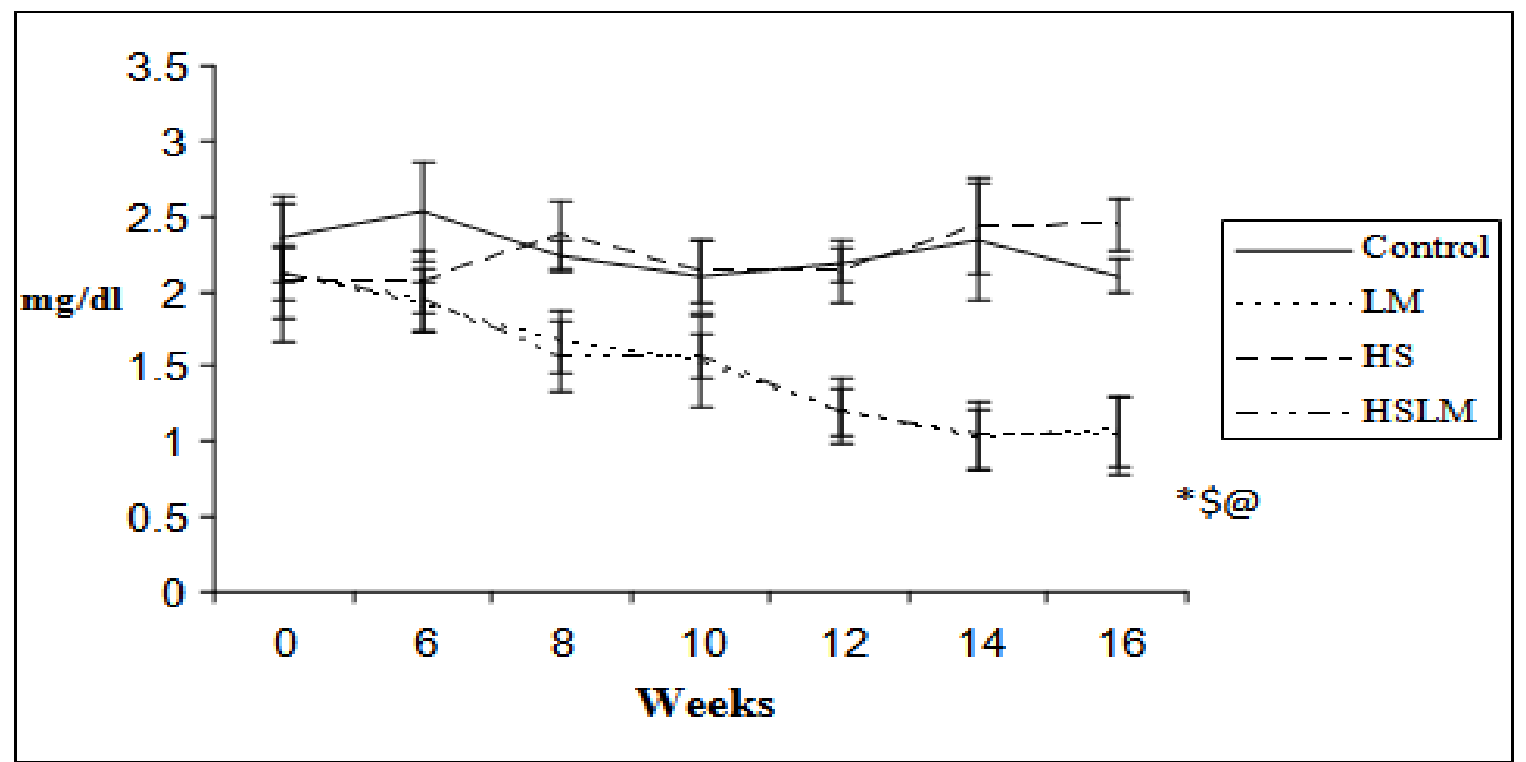

In all cases $\mathrm{p}<0.001$

* Significantly different from the initial value, \$ Significantly different from the control group, ${ }^{\circledR}$ Significantly different from the HS group.

Fig. 2: Plasma magnesium levels at $6^{\text {th }}$ to $16^{\text {th }}$ week of diet feeding. The figure indicates a marked decrease in the plasma magnesium content in rats fed HSLM diet in comparison to control rats. 


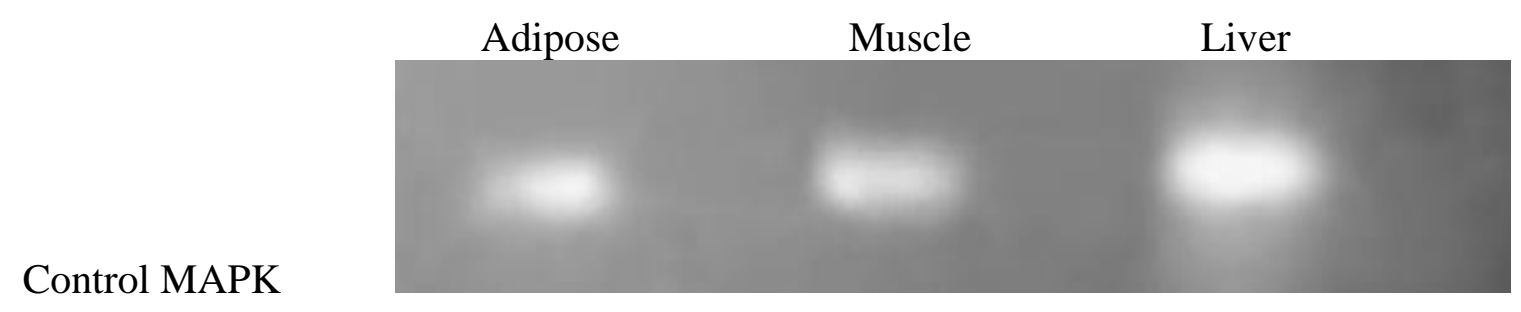

Beta actin

LM MAPK

Beta actin

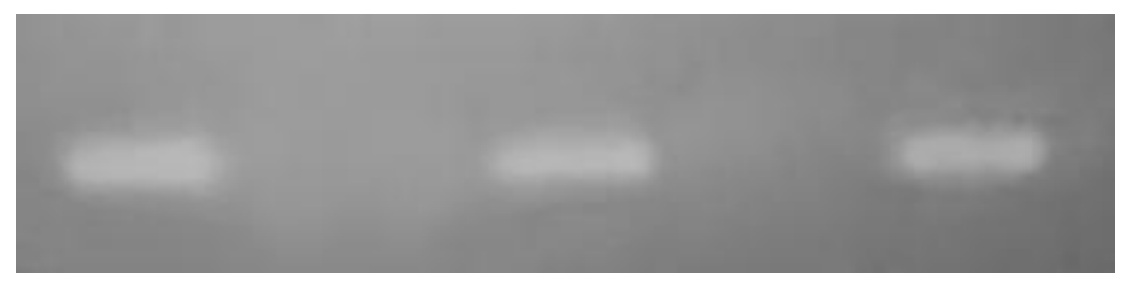

HS MAPK

Beta actin

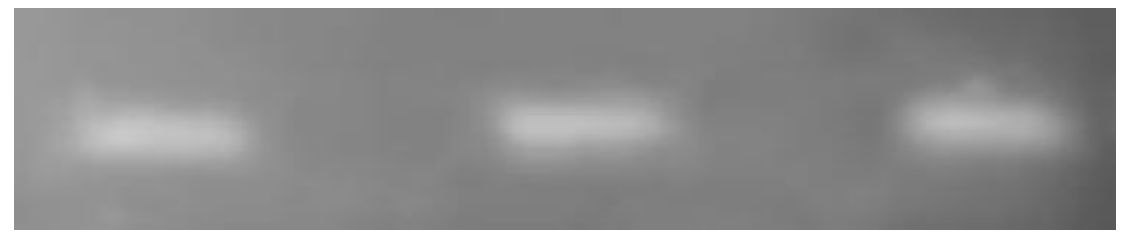

HSLM MAPK

Beta actin
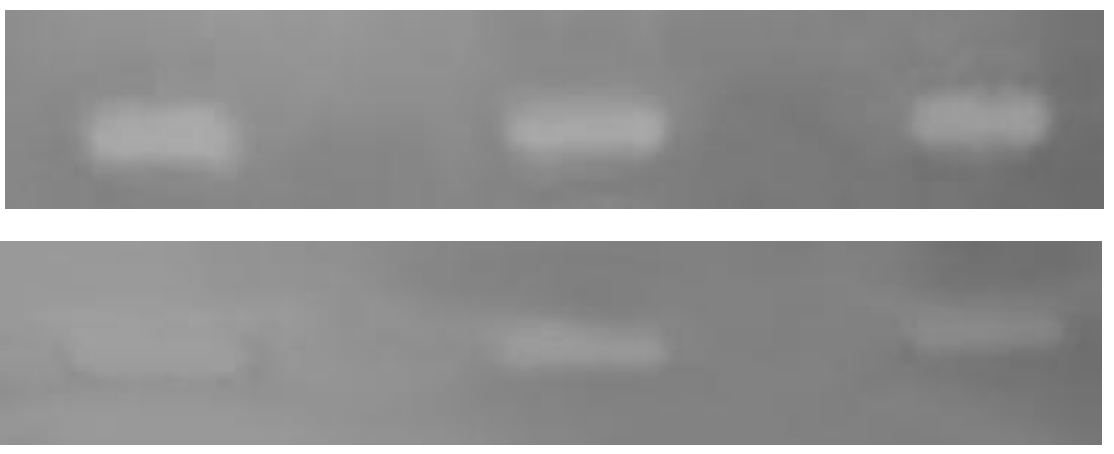

Fig. 3: Agarose gel electrophoresis of RT-PCR products of ERK2 and $\beta$-actin from adipose tissue, skeletal muscle and liver of Control, LM, HS and HSLM diet fed rats. 
Control PI3K

Beta actin

LM PI3K

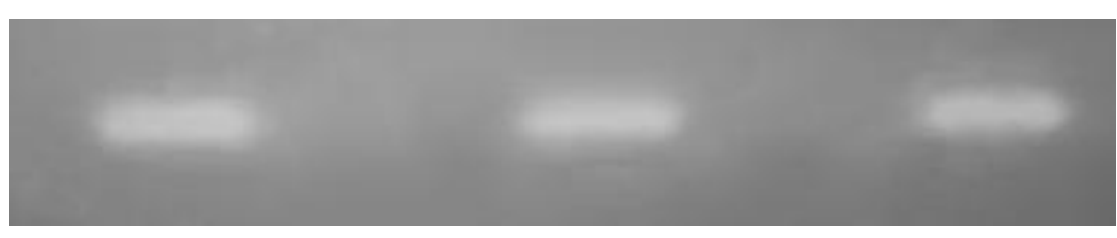

Beta actin

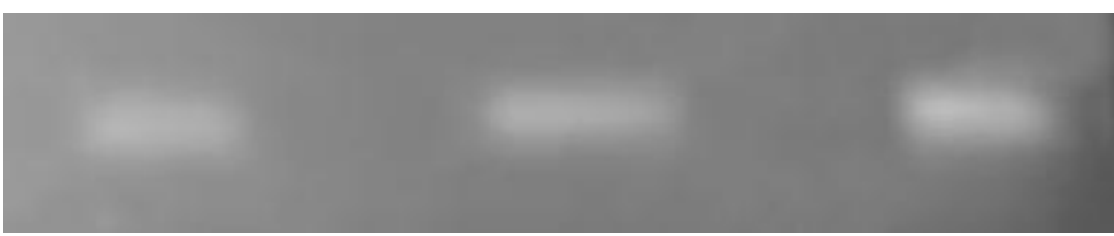

HS PI3K

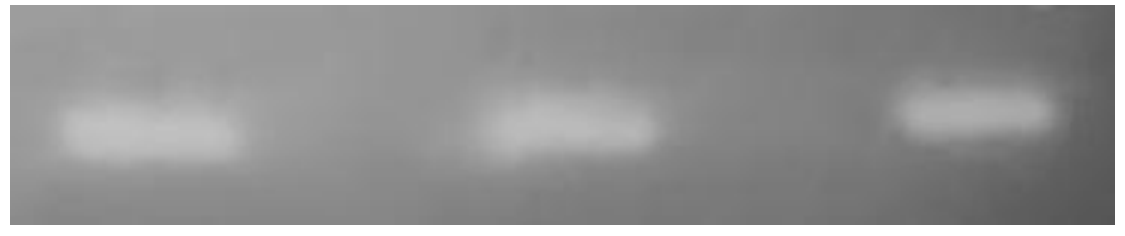

Beta actin
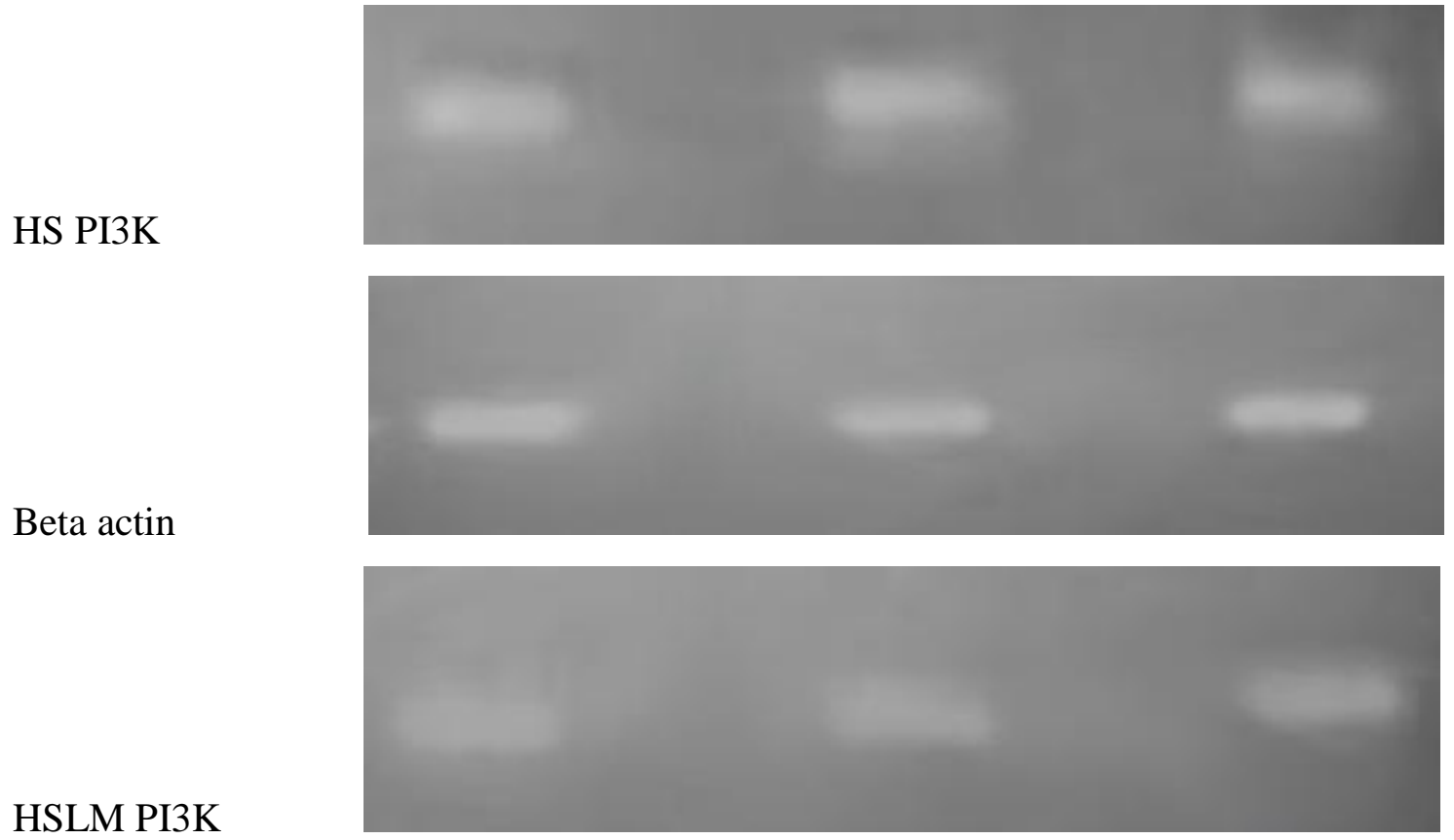

HSLM PI3K
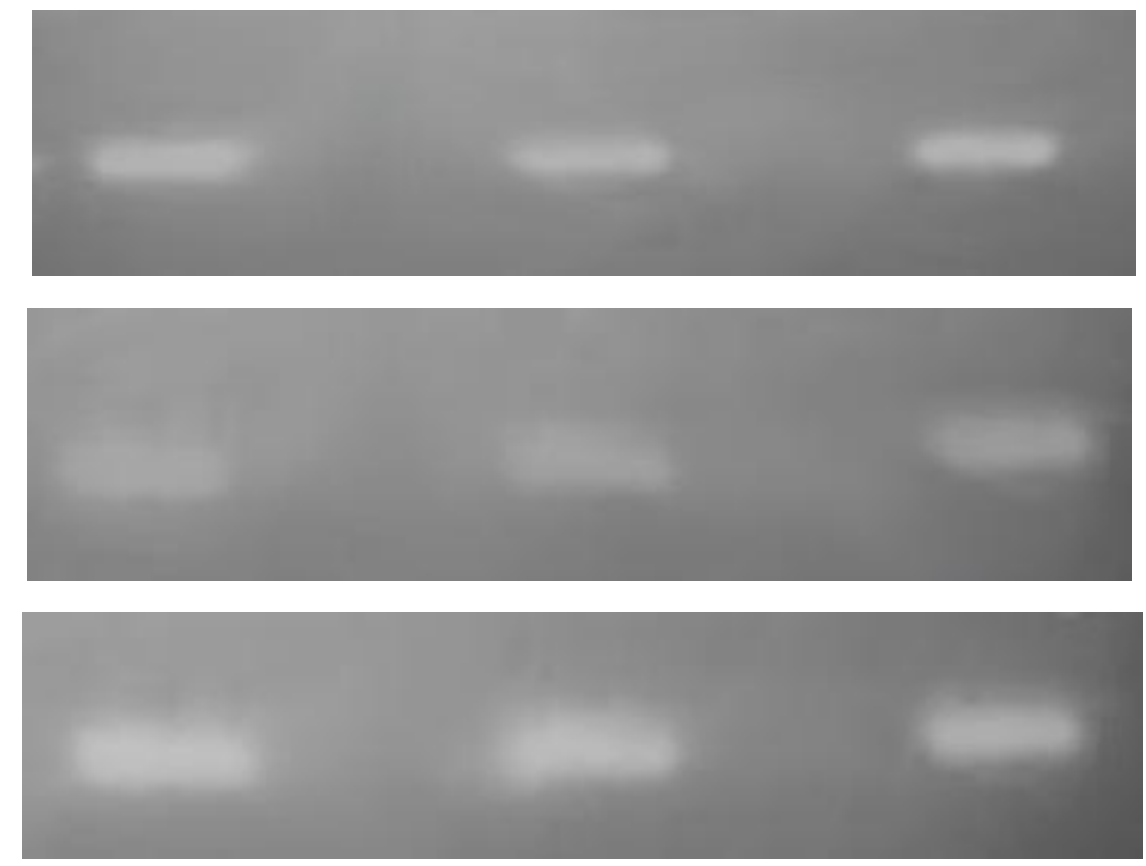

Beta actin

Fig. 4: Agarose gel electrophoresis of RT-PCR products of PI3K and $\beta$-actin from adipose tissue, skeletal muscle and liver of Control, LM, HS and HSLM diet fed rats. 


\section{Results}

\subsection{Animal model preparation by feeding High Sucrose Low Magnesium diet to rats}

Levels of Plasma glucose and magnesium were monitored on a biweekly basis after feeding rats the experimental diets for a period of 4 weeks. Results obtained clearly show marked hyperglycemia and hypomagnesemia in rats fed HSLM diet when compared to rats fed a control diet (Table 3, 4; Fig 1, 2).

\subsection{RNA Isolation and RT-PCR:}

At the end of 4 months of diet feeding the overnight fasted rats were sacrificed and RNA was isolated from adipose tissue, skeletal muscle and liver. Total RNA was then subjected to RT-PCR analysis and the products thus obtained were run on a $2 \%$ agarose gel. Results obtained clearly show a marked decrease in the density of the cDNA products from the tissues of rats fed a high sucrose low magnesium diet when compared to that of control rats indicating a downregulated expression of both ERK2 and PI3K in all the three tissues. (Fig. 3-6).

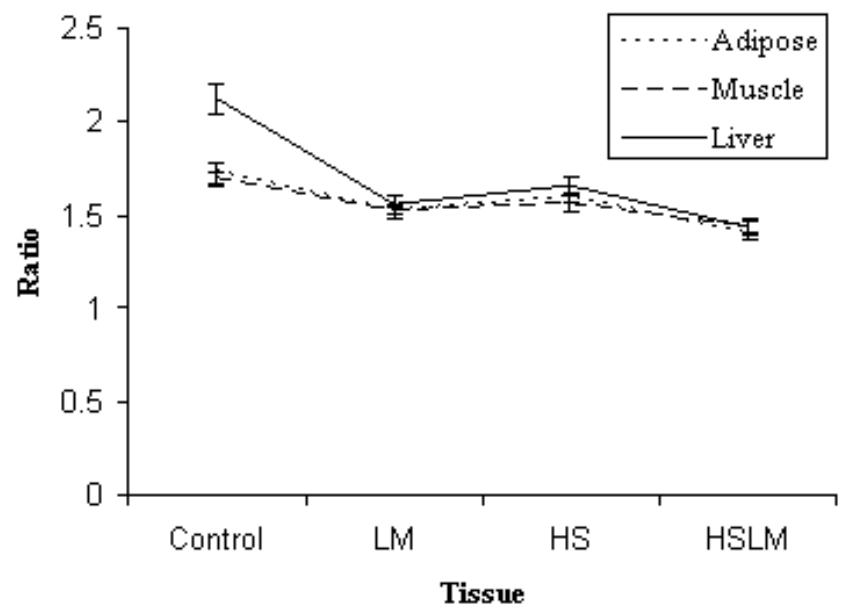

Fig. 5: MAPK/ $\beta$-actin ratio in adipose, skeletal muscle and liver tissue of rats fed different diets.

\subsection{Change in expression}

Percentage change in the expression of both the enzymes was calculated. Our results clearly Am. J. Biomed. Sci. 2011, 3(1), 11-22; doi: 10.5099/aj110100011 show a significant percentage downregulation of both of the kinases in all the three tissues in rats fed HSLM diet when compared to those fed a control diet.

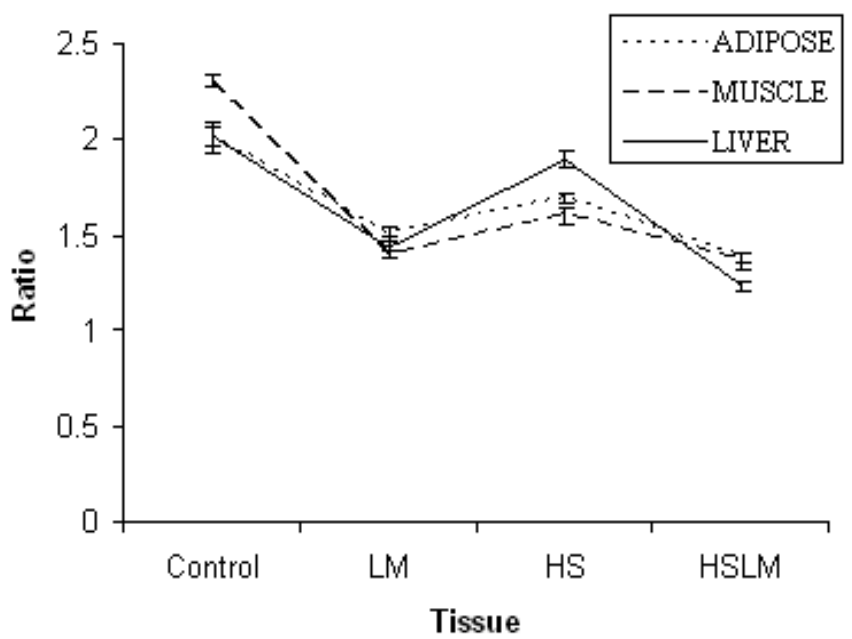

Fig. 6: PI3K/ $\beta$-actin ratio in adipose, skeletal muscle and liver tissue of rats fed different diets.

\section{Discussion}

Feeding rats a high sucrose low magnesium diet leads to hyperglycemia, hypertriglyceridemia, hyperinsulinemia [11], insulin resistance, and if continued long enough, impaired glucose tolerance or diabetes $[14,15]$. The present study was carried out to develop an insulin resistant rat model by feeding HSLM diet to weanling rats and to study the expression of the downstream effectors of the insulin signaling pathway, viz. ERK2 and PI3 Kinase in this rat model. To achieve this, rats in different groups were fed respective diets and the plasma concentration of glucose and magnesium were monitored on a biweekly basis for 12 weeks to observe any difference as compared to control rats. Our results clearly show that sucrose overfeeding and inadequate magnesium intake in experimental animals resulted in hyperglycemia $[p<0.05]$ in both low magnesium (LM) as well as high sucrose (HS) groups. The animals in the group fed HSLM diet also had elevated plasma glucose levels, with the likelihood that both carbohydrate (sucrose) (c) 2011 by NWPII. All rights reserved. 
overfeeding and hypomagnesaemia contribute to the abnormal glucose levels in the plasma of experimental rats. Studies have illustrated the detrimental effects of sucrose rich diets on glucose homeostasis [16] and it is possible that the hyperglycemia associated with sucrose-rich diets might be due partially to several reasons including perturbations in the activities of crucial enzymes leading to a change in flux through the pathways. Magnesium deficient diets are implicated in causing hypomagnaesemia ( in approximately 3 months of diet feeding [11] ). It has been observed that omission of extacellular magnesium inhibited glucose stimulation of insulin homeostasis in isolated islet cells [17]. The mechanisms of this inhibition could be linked to the ability of glucose and several other stimulators of insulin biosynthesis to increase magnesium uptake by islet cells [18, 19]. Our results on the concentration of magnesium in the plasma of experimental animals are presented in Fig 2 . Plasma magnesium levels in HS diet group were comparable to control in our study indicating that feeding a low magnesium diet, irrespective of the carbohydrate component of the diet, resulted in a marked lowering $[p<0.05]$ of plasma magnesium levels. Our results are consistent with the previous studies reporting significantly decreased plasma magnesium levels in rats fed a low magnesium diet [20-22].

Once the model was established, the expression of PI3 kinase and MAP Kinase (ERK2) was studied in adipose, skeletal muscle and liver tissues of rats. Our results clearly show a significant decrease in the expression of both kinases in all the three tissues in HSLM diet fed rats when compared to control rats. Our findings are consistent with the studies showing that both basal and insulin stimulated ERK2 activity are markedly reduced in obese rats [23]. Reports clearly demonstrate that insulin receptor signaling through the PI3-Kinase pathway is reduced in the Zucker rat model of insulin resistance and the same has been shown in our model of HSLM diet fed rats.

Insulin is known to be an important modulator of the cellular content of $\mathrm{Mg}$ [24,25]. Since Mg is a necessary cofactor in all ATP transfer reactions, this implies that $\left[\mathrm{Mg}^{2+}\right]_{\mathrm{i}}$ concentration is critical in the phosphorylation of the insulin receptor [26]. Insulin binding to specific cell surface receptors leads to the activation of protein kinase which is an important step in transmembrane signaling for insulin action [27]. There are several examples where alteration in receptor kinase activity could explain an impairment of insulin action [28]. Insulin receptors isolated from various tissues of type 2 diabetics or obese subjects have an impaired capacity to autophosphorylate or express the tyrosine kinase activity when exposed to insulin [29]. Suáres et al. suggested that the insulin resistance observed in the skeletal muscles of magnesium-deficient rats might be attributed to the defective tyrosine kinase activity of the insulin receptor [30]. Studies in multiple insulin resistant cell models have demonstrated that an impaired response of the tyrosine kinase to insulin stimulation is one potential mechanism causing insulin resistant-state in type 2 diabetes [31]. Similarly, a depletion of $\left[\mathrm{Mg}^{2+}\right]$ may cause a defective tyrosine kinase function at the insulin receptor level.

A decreased concentration of $\left[\mathrm{Mg}^{2+}\right]$ is associated with a diminution in the ability of insulin to stimulate glucose uptake in insulinsensitive tissues, such as adipose cells and skeletal muscle tissues [32]. Given in vitro evidence that low $\mathrm{Mg}$ concentrations can reduce tissue glucose uptake $[33,34]$, it seems that reduced $\left[\mathrm{Mg}^{2+}\right]$ interferes with the insulin signaling mechanism involved in glucose transport [35]. Altered $\left[\mathrm{Mg}^{2+}\right.$ ] may also lead to decreased cellular glucose utilization, thus promoting peripheral insulin resistance with a postreceptor mechanism.

High sucrose feeding has long been implicated in leading to insulin resistance at some point of time and the most damage has been attributed to the fructose component of sucrose. Studies of fructose fed models of insulin resistance show that despite the normal number of insulin receptors in the liver and muscle of fructose-fed rats, there was a $29 \%$ reduction in insulin receptor autophosphorylation in the liver after stimulation with insulin "in vivo." The decrease observed here may be of biological importance because a reduction in receptor phosphorylation has been correlated with insulin resistance in different animal models [34-36]. 
There was a significant reduction in the level of hepatic and muscle IRS-1 tyrosine phosphorylation, followed by a reduction in IRS1/PI 3-kinase association in liver and muscle. In previous studies of fructose-fed rats, a reduced ability of insulin to suppress hepatic glucose production has been implicated as one of the elements of insulin resistance [37, 38]. The IRS1/PI 3-kinase association induced by insulin is necessary, and in some cases sufficient to elicit many of the insulin effects on glucose and lipid metabolism. The products of PI 3-kinase act as both membrane anchors and allosteric regulators, serving to locate and activate downstream enzymes and their protein substrates [39]. Thus, the reduction in IRS-1/PI 3-kinase association in the liver of fructose-fed rats may have a role in insulin resistance.

On the basis of results of this study, we conclude that feeding high sucrose low magnesium diet to weanling rats resulted in marked hyperglycemia as well as hypomagnaesemia which are hallmarks of type 2 diabetes. This suggests that we have been able to develop a type 2 diabetic rat model by feeding HSLM diet for a period of 4 months. Our results also show a decreased expression of PI3 Kinase and ERK2 in the adipose, skeletal muscle and liver tissues of HSLM diet fed rats when compared to control, although the mechanism leading to this is not yet clear and paves way for future studies.

\section{Abbreviations}

MAPK Mitogen-Activated Protein Kinase

ERK Extracellular Signal-Regulated Kinase

PI3 K Phosphatidylinositol- 3-Kinase

IRS Insulin Receptor Substrate

GLUT Glucose Transporter

RT-PCR Reverse Transcriptase- Polymerase Chain Reaction

\section{References}

1. Bray, G. A.; Nielsen, S. J.; Popkin, B. M.Consumption of high-fructose corn syrup in

Am. J. Biomed. Sci. 2011, 3(1), 11-22; doi: 10.5099/aj110100011 beverages may play a role in the epidemic of obesity. Am. J. Clin. Nutr., 2004 ,79, 537-543.

2. Pagliassotti, M. J.; Prach, P. A.; Koppenhafer, T. A.; Pan, D. A. Changes in insulin action, triglycerides, and lipid composition during sucrose feeding in rats. Am. J. Physiol., 1996, 271, R1319-R1326.

3. Gueux, E.; Rayssiguier, Y. The effect of magnesium deficiency on glucose stimulated insulin secretion in rats. Horm. Metab. Res., 1983, 15, 594-597.

4. Paolisso, G.; Scheen, A.; D’Onofrio, F.; Lefe`bvre, P. Magnesium and glucose homeostasis. Diabetologia , 1990, 33, 511514.

5. Endemann, G.; Yonezawa, K.; Roth, R. Phosphatidylinositol kinase or an associated protein is a substrate for the insulin receptor kinase. J. Biol. Chem., 1990, 265, 396-400.

6. Kanai, F.; Ito, K.; Todaka, M.; Hayashi, H.; Kanohara, S.; Ishii, K.; Okada, T.; Hazeki, O.; Ui, M.; Ebina, Y. Insulin-stimulated GLUT4 translocation is relevant to the phosphorylation of IRS-1 and the activity of PI3-kinase. Biochem. Biophys. Res. Comm., 1993, 195, 762-768.

7. Lazar, D.; Weise, R.; Brady, M.; Mastrik, C.; Waters, S.; Yamauchi, K.; Pessin, J.; Cuatrecasas, P.; Saltiel, A.J. Mitogen activated protein kinase kinase inhibition does not block the stimulation of glucose utilization by insulin. J. Biol. Chem., 1995, 270, 2080120807.

8. Zheng, C.F.; Guan, K.L. Properties of MEKs, the kinases that phosphorylate and activate the extracellular signal-regulated kinases. J. Biol. Chem., 1993, 268, 23933-23939.

9. Anai, M.; Funaki, M.; Ogihara, T.; Terasaki, J.; Inukai, K.; Katagiri, H.; Fukushima, Y.; Yazaki, Y.; Kikuchi, M.; Oka, Y.; Asano, T. Altered expression levels and impaired steps in the pathway to phosphatidylinositol 3-kinase activation via insulin receptor substrates 1 and 2 in Zucker fatty rats. Diabetes, 1998, 47, 1323.

10. Bjornholm, N.; Kawano, Y.; Lehtihet, M.; Zierath, J.R. Insulin receptor substrate-1 phosphorylation and phosphatidylinositol 3kinase activity in skeletal muscle from 
NIDDM subjects after in vivo insulin stimulation. Diabetes, 1997, 46, 524-527.

11. Chaudhary, D.P.; Boparai, R.K.; Sharma, R.; Bansal, D.D. Studies on the development of an insulin resistance rat model by chronic feeding of high sucrose low magnesium diet. Magnesium Res., 2004, 17, 293-300.

12. Trinder, P. Determination of glucose in blood using glucose oxidase with an alternative oxygen acceptor. Ann. Clin. Biochem., 1969, 6, 24-25.

13. Thuvasethakul, P.; Wajjwalku, W. Serum magnesium determined by use of methyl thymol blue. Clin. Chem., 1987, 33, 614-615.

14. Kragen, E. W.; James, D. E.; Storlien, L. H.; Burleigh, K. M.; Chisholm, D. J. In vivo insulin resistance in individual peripheral tissues of the high fat fed rat: assessment by euglycaemic clamp plus deoxyglucose administration. Diabetologia,1986, 29, 192198.

15. Storlien, L. H.; James, D. E.; Burleigh, K. M.; Chisholm, D. J.; Kragen, E. W. Fat feeding causes widespread in vivo insulin resistance, decreased energy expenditure, and obesity in rats. Am. J. Physiol, 1986, 251, E576-E583.

16. Storlein, L.H.; James, D.E.; Burleigh, K.M.; Chisholm, D.J.; Kragen, E.W. Effects of sucrose vs. starch diets on in vivo insulin action, thermogenesis and obesity in rats. Am. J. Clin. Nutr. , 1988, 47, 420-427.

17. Lin, B.J.; Haist, R.E. Effects of some modifiers of insulin secretion on insulin biosynthesis. Endocrinology, 1973, 92, 735742.

18. Henquin, J.C.; Nenquin, M.; Awouters, P.; Cogneau, M. Magnesium uptake by islet cells is modulated by stimulators and inhibitors of the B-cell function. Eur. J. Biochem. , 1986, 155, 653-657.

19. Henquin, J.C.; Tamagawa, T.; Nenquin, M.; Cogneau, M. Glucose modulates $\mathrm{Mg}^{2+}$ fluxes in pancreatic islet cells. Nature, 1983, 301, 7374.

20. McNeill, D.A.; Herbrein, J.H.; Ritchey S.J. Hepatic gluconeogenic enzymes, plasma insulin and glucagons response to magnesium deficiency and fasting. J. Nutr., 1982, 112, 736-743.
21. Suarez, A.; Pulido, N.; Casla, A.; Casanova, B.; Arrieta, F.J.; Rovira, A. Impaired tyrosinekinase activity of muscle insulin receptors from hypomagnesaemic rats. Diabetologia, 1995, 38, 1262-1270.

22. Hans, C.P.; Chaudhary, D.P.; Bansal, D.D. Magnesium deficiency increases oxidative stress in rats. Ind. J. Exptl. Biol., 2002, 40, 1275-1279.

23. Osman, A.A.; Hancock, J.; Hunt, D.G.; Ivy, J.; Mandarino, L.J. Exercise training increases ERK2 activity in skeletal muscle of obese Zucker rats. J. Appl .Physiol., 2001, 90, 454 460.

24. Lostroh, A.J.; Krahl, M.E. Accumulation in vitro of $\mathrm{Mg}^{2+}$ and $\mathrm{K}^{+}$in rat uterus: ion pump activity. Bioch. Biophys. Acta., 1973, 291, 260-68.

25. Hwang, D.L.; Yen, C.F.; Nadler, J.L. Insulin increases intracellular magnesium transport in human platelets. J. Clin. Endocrinol. Metab. , 1993, 76, 549-53.

26. Barbagallo, M.; Gupta, R.K.; Bardicef, M.; Resnick, L.M. Altered ionic effects of insulin in hypertension role of basal ion levels in determining cellular responsiveness. J. Clin. Endocrinol. Metab., 1997, 82, 1761-5.

27. Farese, R.V. Function and dysfunction of aPKC isoforms for glucose transport in insulin-sensitive and insulin-resistant states. Am. J. Physiol .Endocrinol. Metab., 2002, 283, E1-E11.

28. Caro, J.F.; Ittoop, O.; Pories, W.J. Studies on the mechanism of insulin resistance in the liver from humans with noninsulin-dependent diabetes. J. Clin. Inves., 1986, 78, 249-58.

29. Maegawa, H.; Shigeta, T.; Egawa, K.; Kobayashi, M. Impaired autophosphorylation of insulin receptors from abdominal skeletal muscle in nonobese subjects with NIDDM. Diabetes, 1991, 40, 815-9.

30. Suáres, A.; Pulido, N.; Casla, A.; Casanova, B.; Arrieta, F.J.; Rovira, A. Impaired tyrosinekinase activity of muscle insulin receptors from hypomagnesaemic rats. Diabetologia, 1995, 38, 1262-70.

31. Haring, H.U. The insulin receptor: signaling, mechanism and contribution to the 
pathogenesis of insulin resistance. Diabetologia, 1991, 34, 848-61.

32. Kandeel, F.R.; Balon, E.; Scott, S.; Nadler, J.L. Magnesium deficiency and glucose metabolism in rat adipocytes. Metabolism, 1996, 45, 838-43.

33. Whitelaw, D.C.; Gilbey, S.G. Insulin resistance. Ann. Clin. Biochem., 1998, 35, 56783.

34. Carvalho, C.R.O.; Brenelli, S. L.; Silva, A. C.; Nunes, A.L.B.; Velloso, L. A.; Saad, M.J.A. Effect of aging on insulin receptor, insulin receptor substrate- 1, and phosphatidylinositol 3-kinase in liver and muscle of rats. Endocrinology, 1996, 137, 151-159.

35. Saad, M.J.A.; Folli, F.; Kahn, J.; Kahn, C. R. Modulation of insulin receptor, insulin receptor substrate-1, and phosphatidylinositol 3-kinase in liver and muscle of dexamethasone-treated rats. J. Clin. Investig., 1993, 92, 2065- 2072.
36. Saad, M.J.A.; Maeda, L.; Brenelli, S. L.; Paiva, L. A.; Velloso, L. A. Defects in insulin signal transduction in liver and muscle of pregnant rats. Diabetologia, 1997, 40, 179186.

37. Thorburn, A. W.; Storlien, L. H.; Jenkins, A. B.; Khouri, S.; Kraegen, E. W. Fructoseinduced in vivo insulin resistance and elevated plasma triglyceride levels in rats. Am. J. Clin. Nutr., 1989, 49, 1155-1163.

38. Tobey, T. A.; Mondon, C. E.; Zavaroni, I.; Reaven, G. M. Mechanism of insulin resistance in fructose-fed rats. Metabolism, 1982, 31, 608-612.

39. Shepherd, P. R.; Withers, D. J.; Siddle, K. Phosphoinositide 3-kinase: the key switch mechanism in insulin signalling. Biochem. J., 1998, 333, 471-490. 